Marquette University

e-Publications@Marquette

$4-2010$

\title{
Common Neural Systems Associated with the Recognition of Famous Faces and Names: An Event-Related fMRI Study
}

\author{
Kristy A. Nielson \\ Marquette University, kristy.nielson@marquette.edu \\ Michael Seidenberg \\ Rosalind Franklin University of Medicine and Science \\ John L. Woodard \\ Wayne State University \\ Sally Durgerian \\ Medical College of Wisconsin \\ Qi Zhang \\ Medical College of Wisconsin
}

See next page for additional authors

Follow this and additional works at: https://epublications.marquette.edu/psych_fac

Part of the Psychology Commons

\section{Recommended Citation}

Nielson, Kristy A.; Seidenberg, Michael; Woodard, John L.; Durgerian, Sally; Zhang, Qi; Gross, William L.; Gander, Amelia; Guidotti, Leslie; Antuono, Piero; and Rao, Stephen M., "Common Neural Systems Associated with the Recognition of Famous Faces and Names: An Event-Related fMRI Study" (2010). Psychology Faculty Research and Publications. 129.

https://epublications.marquette.edu/psych_fac/129 


\section{Authors}

Kristy A. Nielson, Michael Seidenberg, John L. Woodard, Sally Durgerian, Qi Zhang, William L. Gross, Amelia Gander, Leslie Guidotti, Piero Antuono, and Stephen M. Rao 


\title{
Common Neural Systems Associated with The Recognition of Famous Faces and Names: An Event-Related fMRI Study
}

\author{
Kristy A. Nielson \\ Department of Psychology and the Integrative Neuroscience \\ Research Center, Marquette University \\ Foley Center for Aging and Development \\ Medical College of Wisconsin \\ Functional Imaging Research Center \\ Medical College of Wisconsin \\ Department of Psychiatry, Medical College of Wisconsin \\ Department of Neurology, Medical College of Wisconsin, \\ Milwaukee, WI \\ Michael Seidenberg \\ Foley Center for Aging and Development \\ Medical College of Wisconsin \\ Functional Imaging Research Center \\ Medical College of Wisconsin \\ Milwaukee, WI \\ Department of Psychology, Rosalind Franklin University of \\ Medicine and Science \\ North Chicago, IL
}


NOT THE PUBLISHED VERSION; this is the author's final, peer-reviewed manuscript. The published version may be accessed by following the link in the citation at the bottom of the page.

\author{
John L. Woodard \\ Foley Center for Aging and Development \\ Medical College of Wisconsin \\ Functional Imaging Research Center \\ Medical College of Wisconsin \\ Milwaukee, WI \\ Department of Psychology, Rosalind Franklin University of \\ Medicine and Science \\ North Chicago, IL \\ Department of Psychology, Wayne State University \\ Detroit, $M I$ \\ Sally Durgerian \\ Functional Imaging Research Center \\ Medical College of Wisconsin \\ Department of Neurology \\ Medical College of Wisconsin \\ Milwaukee, WI \\ Qi Zhang \\ Functional Imaging Research Center \\ Medical College of Wisconsin \\ Department of Neurology \\ Medical College of Wisconsin \\ Milwaukee, WI \\ William L. Gross \\ Functional Imaging Research Center \\ Medical College of Wisconsin \\ Department of Neurology \\ Medical College of Wisconsin \\ Milwaukee, WI \\ Amelia Gander \\ Functional Imaging Research Center \\ Medical College of Wisconsin \\ Department of Neurology \\ Medical College of Wisconsin
}

Brain and Cognition, Vol 72, No. 3 (April 2010): pg. 491-498. DOI. This article is @ Elsevier and permission has been granted for this version to appear in e-Publications@Marquette. Elsevier does not grant permission for this article to be further copied/distributed or hosted elsewhere without the express permission from Elsevier. 
NOT THE PUBLISHED VERSION; this is the author's final, peer-reviewed manuscript. The published version may be accessed by following the link in the citation at the bottom of the page.

\author{
Milwaukee, WI \\ Leslie M. Guidotti \\ Functional Imaging Research Center \\ Medical College of Wisconsin \\ Milwaukee, WI \\ Department of Psychology, Rosalind Franklin University of \\ Medicine and Science \\ North Chicago, IL \\ Piero Antuono \\ Foley Center for Aging and Development \\ Medical College of Wisconsin \\ Functional Imaging Research Center \\ Medical College of Wisconsin \\ Department of Neurology \\ Medical College of Wisconsin \\ Milwaukee, WI \\ Stephen M. Rao \\ Foley Center for Aging and Development \\ Functional Imaging Research Center \\ Department of Psychiatry \\ Department of Neurology \\ Medical College of Wisconsin \\ Milwaukee, WI \\ Department of Psychology, Rosalind Franklin University of \\ Medicine and Science \\ North Chicago, IL \\ Schey Center for Cognitive Neuroimaging, Cleveland Clinic \\ Cleveland, $\mathrm{OH}$
}

Abstract: Person recognition can be accomplished through several modalities (face, name, voice). Lesion, neurophysiology and neuroimaging studies have been conducted in an attempt to determine the similarities and differences in the neural networks associated with person identity via different modality inputs. The current study used event-related functional-MRI in 17 healthy participants to directly compare activation in response to randomly

Brain and Cognition, Vol 72, No. 3 (April 2010): pg. 491-498. DOI. This article is @ Elsevier and permission has been granted for this version to appear in e-Publications@Marquette. Elsevier does not grant permission for this article to be further copied/distributed or hosted elsewhere without the express permission from Elsevier. 
presented famous and non-famous names and faces (25 stimuli in each of the four categories). Findings indicated distinct areas of activation that differed for faces and names in regions typically associated with pre-semantic perceptual processes. In contrast, overlapping brain regions were activated in areas associated with the retrieval of biographical knowledge and associated social affective features. Specifically, activation for famous faces was primarily right lateralized and famous names were left lateralized. However, for both stimuli, similar areas of bilateral activity were observed in the early phases of perceptual processing. Activation for fame, irrespective of stimulus modality, activated an extensive left hemisphere network, with bilateral activity observed in the hippocampi, posterior cingulate, and middle temporal gyri. Findings are discussed within the framework of recent proposals concerning the neural network of person identification.

Recognition of a familiar person is typically automatic, quick, and accurate. It can also be accomplished through several input modalities such as by presentation of the face or name of an individual person. It is generally accepted that a diverse set of cognitive operations and a distributed neural network mediates the person recognition and identification process, but the specific details remain a topic of debate and considerable investigation (Bruce \& Young, 1986; Burton, Bruce, \& Johnston, 1990; Gobbini \& Haxby, 2007; Haxby \& Ida Gobbini, 2007; Ishai, Schmidt, \& Boesiger, 2005; Leveroni et al., 2000; Seidenberg et al., 2002; Wiggett \& Downing, 2008).

Several questions about the structure and organization of the person identity system remain unresolved. One issue concerns whether a single amodal general semantic memory system representing person knowledge exists or whether multiple modality specific person identity semantic systems are represented (Gainotti, 2007; Haslam, Kay, Hanley, \& Lyons, 2004; Lambert, Swain, Miller, \& Caine, 2006; Leveroni et al., 2000). Related to this issue are questions about the degree of hemispheric lateralization for faces and names, which regions are involved in the processing of these stimuli, and the identification of shared and unique regions. Data relevant to these issues have come from human lesion studies of person recognition, behavioral studies in healthy subjects, event-related potential studies, and more recently from functional neuroimaging studies. As reviewed below, there is not yet a clear consensus about the answers to these questions.

Brain and Cognition, Vol 72, No. 3 (April 2010): pg. 491-498. DOI. This article is @ Elsevier and permission has been granted for this version to appear in e-Publications@Marquette. Elsevier does not grant permission for this article to be further copied/distributed or hosted elsewhere without the express permission from Elsevier. 
Snowden (2004) examined the performance of 15 semantic dementia patients on famous face and name knowledge. Overall, semantic dementia (SD) patients, who are characterized by primarily anterolateral temporal lobe damage, performed more poorly on both face and name identification and familiarity compared to Alzheimer's disease (AD) patients, with primarily medial temporal lobe damage. Of interest, when the SD group was distinguished on the basis of extent of right or left side temporal lobe damage, there was a clear double dissociation such that those with $\mathrm{R}>\mathrm{L}$ atrophy performed more poorly with faces compared to names, and the L>R atrophy group showed the opposite pattern. These findings are consistent with other lesion studies, which report modality specific deficits for famous faces and names as a function of laterality of lesion (Eslinger, 1996; Evans, Heggs, Antoun, \& Hodges, 1995; Kartsounis \& Shallice, 1996).

Gainotti (2007) provided an extensive review of both case and group studies examining the effect of lateralized left or right temporal lobe lesions on famous people recognition. He concluded that the data were most consistent with a modality-specific proposal. That is, lesions to the right temporal lobe produced impairment in face recognition and the retrieval of person specific knowledge, while left temporal lobe lesions affected retrieval access to the specific name of an individual face but spared face recognition and access to other semantic information about the person (e.g., occupation). In addition, right temporal lobe lesions tended to show a stronger modality-specific effect in that famous faces were less well recognized than famous names, while left temporal lobe lesions tended to show a more balanced deficit for faces and names.

Schweinberger and colleagues (2002) conducted an ERP repetition priming study of famous faces and famous names (in two separate studies), and reported a similar pattern of activity for both stimuli at a late post-recognition time frame (500-600 msecs). They suggested that the findings were consistent with the notion of separate stimulus specific perceptual analyses, but that famous faces and names shared a common source for retrieval of semantic information. A similar conclusion was reached in an ERP study examining agerelated changes to face and name recognition (Pfutze, Sommer, \& Schweinberger, 2002).

Brain and Cognition, Vol 72, No. 3 (April 2010): pg. 491-498. DOI. This article is @ Elsevier and permission has been granted for this version to appear in e-Publications@Marquette. Elsevier does not grant permission for this article to be further copied/distributed or hosted elsewhere without the express permission from Elsevier. 
Functional neuroimaging techniques provide another approach to examine the neural correlates of famous face and name processing. It permits the examination of the person recognition system both in its normal operational state as well as during an impaired state (e.g., lesion) and also can include larger samples of ("normal") subjects. At this point, neuroimaging studies have primarily been devoted to studying famous and non-famous face stimuli, and only a few studies have examined the direct contrast between famous faces and famous names. When just famous faces and non-famous faces are directly contrasted, neuroimaging studies typically show activation in an extensive bilateral cortical and subcortical network, which often has a right sided predominance. This finding is consistent across a number of different task demands including passive viewing, (Ishai et al., 2005), matching faces (Gorno-Tempini et al., 1998), fame discrimination (Leveroni et al., 2000) and face identity (Kapur, Friston, Young, Frith, \& Frackowiak, 1995; Sergent, Ohta, \& MacDonald, 1992). Regions of activation typically include the fusiform and lingual gyrus, inferior frontal gyrus, hippocampus, posterior cingulate, precuneus, anterior temporal lobe, and both middle and inferior occipital temporal cortex. In a series of studies comparing the event-related BOLD signal for famous names versus non-famous names, we found that famous names also activated an extensive bilateral network that included many of the same areas observed for famous faces (Douville et al., 2005; Nielson et al., 2006; Woodard et al., 2007).

Gorno-Tempini et al. (1998) conducted a PET study contrasting the processing of famous faces relative to famous names. They found that faces compared to names produced bilateral activation in the fusiform gyri (particularly on the right) and in the right lingual gyrus, whereas the processing of names relative to faces resulted in activation in the left middle temporal gyrus and left superior temporal sulcus. In addition, a shared set of regions activated by both famous faces and names was primarily left-lateralized and included the left temporoparietal junction, left middle inferior temporal gyrus, left medial frontal lobe, and left precuneus.

In the current study, we employed a 2 (fame; famous/nonfamous) by 2 (stimulus type; name/face) within-subjects, eventrelated fMRI design, in order to identify the unique and shared regions associated with accessing name and face familiarity. This design also

Brain and Cognition, Vol 72, No. 3 (April 2010): pg. 491-498. DOI. This article is (C Elsevier and permission has been granted for this version to appear in e-Publications@Marquette. Elsevier does not grant permission for this article to be further copied/distributed or hosted elsewhere without the express permission from Elsevier. 
provided several key improvements over previous studies. Specifically, we used previously verified, highly recognizable famous face and name stimuli and all stimuli were presented in random order. Additionally, the event-related design allowed computation of hemodynamic response functions associated with each stimulus type and the removal of error trials, preventing error biases in the activation maps. Based on the available person-identity network (PIN) literature, we predicted that both famous face and famous name networks would produce a primarily left sided network which would include the posterior cingulate/precuneus regions, anterior temporal lobe, superior frontal region and the temporoparietal junction. We also expected regions of non-overlap that would be associated with "early" or pre-semantic stages, such as the fusiform and lingual gyri (faces) and the left middle temporal gyrus (names).

\section{Materials and Methods}

\section{Participants}

Seventeen healthy adults ( 10 males; mean age $=28.8$ yrs., range $=20-47$; mean education $=17.5$ yrs., range $=14-23$ ) were recruited from universities in the Milwaukee, WI metropolitan area. Participants were excluded if they reported a history of neurological disease, medical illnesses, major psychiatric disturbance meeting DSM-IV Axis I criteria, substance abuse meeting DSM-IV Axis I criteria, or current use of psychoactive medications. Additional exclusion criteria related to fMRI scanning safety and suitability included pregnancy, weight inappropriate for height, ferrous objects within the body, low visual acuity, left-handedness, and a history of claustrophobia. Informed consent was obtained consistent with institutional guidelines established by the Medical College of Wisconsin Human Research Protections Program. All participants received financial compensation. Participants were asked to refrain from alcohol use 24 hours and caffeine use 12 hours prior to the fMRI scan.

Brain and Cognition, Vol 72, No. 3 (April 2010): pg. 491-498. DOI. This article is @ Elsevier and permission has been granted for this version to appear in e-Publications@Marquette. Elsevier does not grant permission for this article to be further copied/distributed or hosted elsewhere without the express permission from Elsevier. 
NOT THE PUBLISHED VERSION; this is the author's final, peer-reviewed manuscript. The published version may be accessed by following the link in the citation at the bottom of the page.

\section{Procedures}

\section{Fame Discrimination Task}

While undergoing fMRI scanning, participants were presented with a series of 100 visual stimuli: 25 names of famous persons, 25 names of non-famous individuals, 25 faces of famous persons, and 25 faces of non-famous individuals. Our previous investigations (e.g., Douville et al., 2005; Nielson et al., 2006; Woodard et al., 2007) using comparable tasks demonstrated stable hemodynamic response functions with as few as 20 trials. Famous and non-famous stimuli were derived from a pool of 361 stimuli generated from previous fMRI studies (Douville et al., 2005; Leveroni et al., 2000). For purposes of this study, the entire set of famous and non-famous stimuli were presented outside the scanner to six participants of similar age and education as the participants included in the current imaging study. Only famous stimuli correctly recognized or non-famous stimuli correctly rejected by at least five of the six participants (83.3\%) were used in the current study. Performance rates for this pilot were: $96.78 \%$ unfamiliar faces ( $\mathrm{sd}=.029$ ), $96.82 \%$ unfamiliar names ( $\mathrm{sd}$ $=.046), 93.14 \%$ familiar faces ( $\mathrm{sd}=.043), 94.62 \%$ familiar names ( $s d=.053)$. Briefly, the famous stimulus sets included comparable distributions of entertainers, politicians and sports figures, while the unfamiliar persons' names were selected from area phone books and photos were selected from various sources where "glamour" photos were available to closely match photos of famous people. Each stimulus set was also balanced for gender and included a wide age range of persons; the famous names and faces sets did not duplicate any individual famous persons.

A trial consisted of the visual presentation of a single name or face for 4 seconds. Participants were instructed to make a right index finger key press if the name or face was famous and a right middle finger key press if the name or face was unfamiliar during this $4 \mathrm{sec}$ interval. The height and width of the names subtended approximate visual angles of $0.2^{\circ}$ and $1.1^{\circ}$, respectively; face images subtended a square $1.1^{\circ}$ on each side.

Brain and Cognition, Vol 72, No. 3 (April 2010): pg. 491-498. DOI. This article is @ Elsevier and permission has been granted for this version to appear in e-Publications@Marquette. Elsevier does not grant permission for this article to be further copied/distributed or hosted elsewhere without the express permission from Elsevier. 
The 100 stimulus trials were randomly interspersed with $1002-$ sec. intervals in which the participant was instructed to fixate on a single centrally placed crosshair. The fixation intervals were incorporated to introduce "jitter" into the fMRI time course. An imaging run began with $6 \mathrm{sec}$. of crosshair fixation. Two imaging runs of 606 sec. each (10 minutes, $6 \mathrm{sec}$.) were required to present the entire set of 100 stimuli.

\section{fMRI Acquisition}

Whole-brain, event-related functional MRI was conducted on a General Electric (Waukesha, WI) 3.0 Tesla long bore scanner equipped with an 8 channel head coil. fMRI images were collected using an gradient-echo, echoplanar pulse sequence (TE $=20.3 \mathrm{msec}$; flip angle $=77$ degrees; field of view $($ FOV $)=24 \mathrm{~cm}$; matrix $64 \times 64)$. Thirty-six contiguous axial, 4-mm-thick slices were selected to provide coverage of the entire brain (voxel size $=3.75 \times 3.75 \times 4 \mathrm{~mm}$ ). The interscan interval (TR) was 2 seconds. High-resolution, three-dimensional spoiled gradient-recalled at steady-state (SPGR) anatomic images were also acquired ( $\mathrm{TE}=3.2 \mathrm{msec}$; $\mathrm{TR}=8.2 \mathrm{msec}$; inversion recovery (IR) preparation time $=450 \mathrm{msec}$; flip angle $=12$ degrees; number of excitations $(\mathrm{NEX})=1$; slice thickness $=1.0 \mathrm{~mm}$; FOV $=24 \mathrm{~cm}$; resolution $=256 \times 224)$. Foam padding was used to reduce head movement within the coil.

\section{fMRI Analysis}

Functional images were generated with Analysis of Functional NeuroImages (AFNI) software (Cox, 1996). Individual anatomical and functional scans were transformed into standard stereotaxic space (Talairach \& Tournoux, 1988). Each image time series was time shifted to the middle of the TR and then spatially registered to reduce the effects of head motion using a rigid body iterative linear least squares method. A deconvolution analysis was used to extract a hemodynamic response (HRF) for each of the four stimulus conditions (Famous Faces, Non-famous Faces, Famous Names, Non-famous Names). HRFs were modeled for the $0-18$ second period post-stimulus onset. Despite a high accuracy rate (see Results), estimation of HRFs were restricted to correct trials. Area under the curve (AUC) of the HRF was calculated by computing sums of the hemodynamic responses at time points 4,6 ,

Brain and Cognition, Vol 72, No. 3 (April 2010): pg. 491-498. DOI. This article is @ Elsevier and permission has been granted for this version to appear in e-Publications@Marquette. Elsevier does not grant permission for this article to be further copied/distributed or hosted elsewhere without the express permission from Elsevier. 
and $8 \mathrm{sec}$. post stimulus onset. To compensate for normal variation in anatomy across subjects, functional images were blurred using a 6 $\mathrm{mm}$ Gaussian full-width half-maximum filter. Functional and structural images were reformatted into $1 \mathrm{~mm}$ isotropic voxels and coregistered.

\section{Spatial Extent Analysis}

This analysis was performed to examine the spatial extent of activation comparing the Famous and Non-famous name conditions. Statistical parametric maps were generated to identify voxels where the AUC for famous names differed significantly from the AUC for nonfamous names. An individual voxel probability threshold of 0.001 $(\mathrm{t}(16)=4.0)$ was applied in conjunction with a minimum cluster size threshold of $0.281 \mathrm{ml}$ (Forman et al., 1995) to minimize false positive activation foci from the brain maps. These two threshold values were derived from a Monte Carlo simulation (3,000 iterations) using the AFNI AlphaSim program indicating that the whole-brain probability of generating a false positive activation cluster is $p=0.05$ (Ward, 2000).

\section{Functional Region of Interest Analyses}

Statistical analysis consisted of a voxelwise, $2 \times 2$ (Stimulus Type by Fame) repeated measures analysis of variance (ANOVA) with pair-wise contrasts for interactions $(p<.05)$. As in the spatial extent analysis, statistical parametric maps used a threshold with a familywise error rate of $p<0.05$.

\section{Results}

\section{Task Performance}

Mean accuracy rates for each condition were as follows: Famous Faces $=90 \%$ (s.d. $=0.10)$, Famous Names $=95 \%$ (s.d. $=0.04$ ), Nonfamous Faces $=91 \%$ (s.d. $=0.05$ ), and Non-famous Names $=97 \%$ (s.d. =0.04). Although all performance means were $90 \%$ correct or better, a two-way, repeated measures ANOVA indicated that the Stimulus Type main effect was significant $(F(1,16)=17.8, p<0.001$, $\eta^{2}=.54$ ) with names being more accurately recognized than faces. The

Brain and Cognition, Vol 72, No. 3 (April 2010): pg. 491-498. DOI. This article is @ Elsevier and permission has been granted for this version to appear in e-Publications@Marquette. Elsevier does not grant permission for this article to be further copied/distributed or hosted elsewhere without the express permission from Elsevier. 
NOT THE PUBLISHED VERSION; this is the author's final, peer-reviewed manuscript. The published version may be accessed by following the link in the citation at the bottom of the page.

Fame main effect and the Fame $\times$ Stimulus Type interaction effect were not significant $(p>0.10)$.

Mean reaction times for each condition were as follows: Famous Faces $=1272 \mathrm{msec}($ s.d. $=225)$, Famous Names $=1186 \mathrm{msec}$ (s.d. = 207), Non-famous Faces $=1685 \mathrm{msec}$ (s.d. = 386), and Non-famous Names $=1625$ msec (s.d. = 407). A two-way, repeated measures ANOVA indicated that the Fame main effect was significant $(F(1,16)=$ 54.9, $\mathrm{p}<0.001, \eta^{2}=.77$ ) with famous individuals being more quickly identified than non-famous individuals. The Stimulus Type main effect and the Fame $\times$ Stimulus Type interaction effect were not significant $(p>0.10)$.

\section{fMRI Results}

\section{Spatial extent analysis}

Results of the voxelwise analysis comparing face and name conditions are shown in Figure $1 \mathrm{~A}$ and Table 1. Of note, Famous Names produced greater activation in the left hemisphere than the right hemispheres $(52.2 \mathrm{ml}$ vs $18.6 \mathrm{ml}$ ) while a right-hemispheric preference was evident for Famous Faces (36 ml vs $12.3 \mathrm{ml}$ ). In addition, as shown in Figure $2 \mathrm{~b}$ and Table 2, the Famous > Nonfamous subtraction produced a greater extent of activation in the left hemisphere compared to the right hemisphere $(34.0 \mathrm{ml}$ vs $3.6 \mathrm{ml})$. 
NOT THE PUBLISHED VERSION; this is the author's final, peer-reviewed manuscript. The published version may be accessed by following the link in the citation at the bottom of the page.

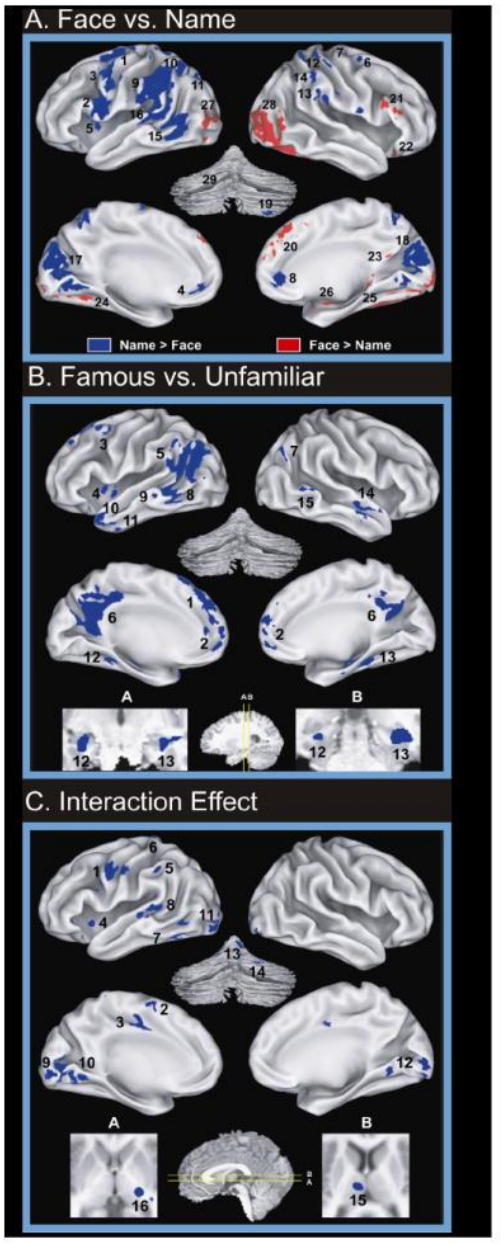

Figure 1. Functional regions of interest (ROI) showing activation for (A) Names > Faces (blue) and Faces > Names (red; ROI numbers correspond to Table 1); (B). Famous stimuli > Non-famous stimuli (blue; no ROIs showed Non-famous > Famous; numbers correspond to Table 2); and (C) ROIs with interactions between Fame and Stimulus Type shown (blue; numbers correspond to Table 3 ). 
NOT THE PUBLISHED VERSION; this is the author's final, peer-reviewed manuscript. The published version may be accessed by following the link in the citation at the bottom of the page.

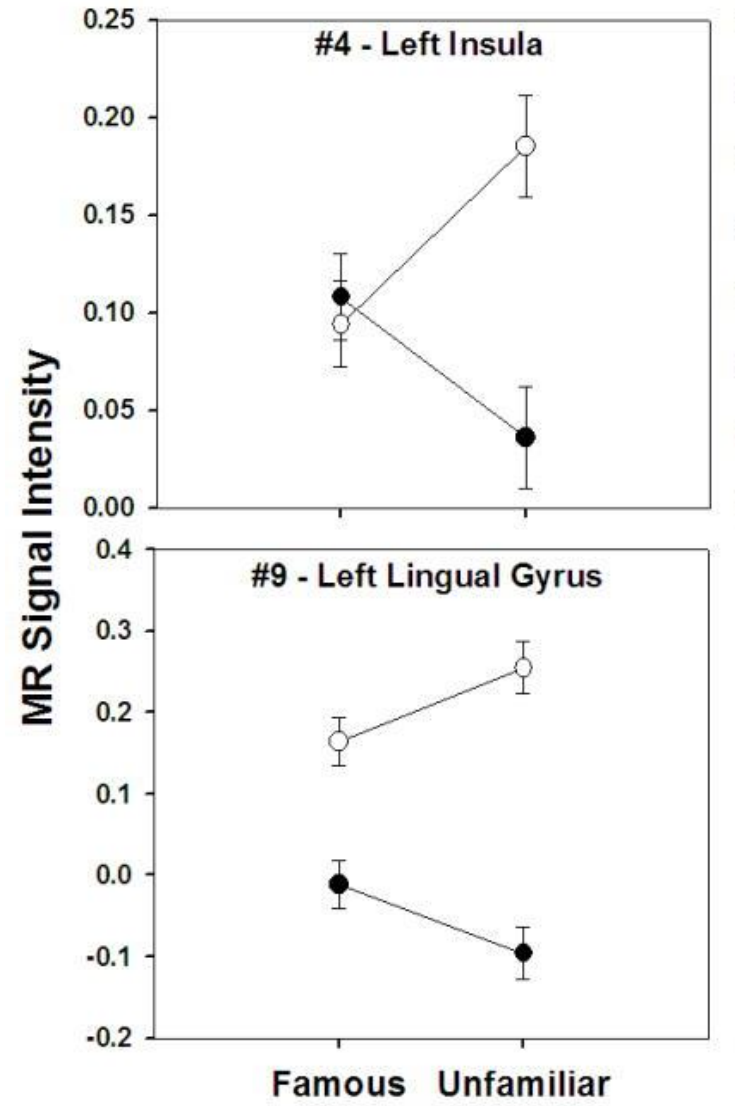

Names
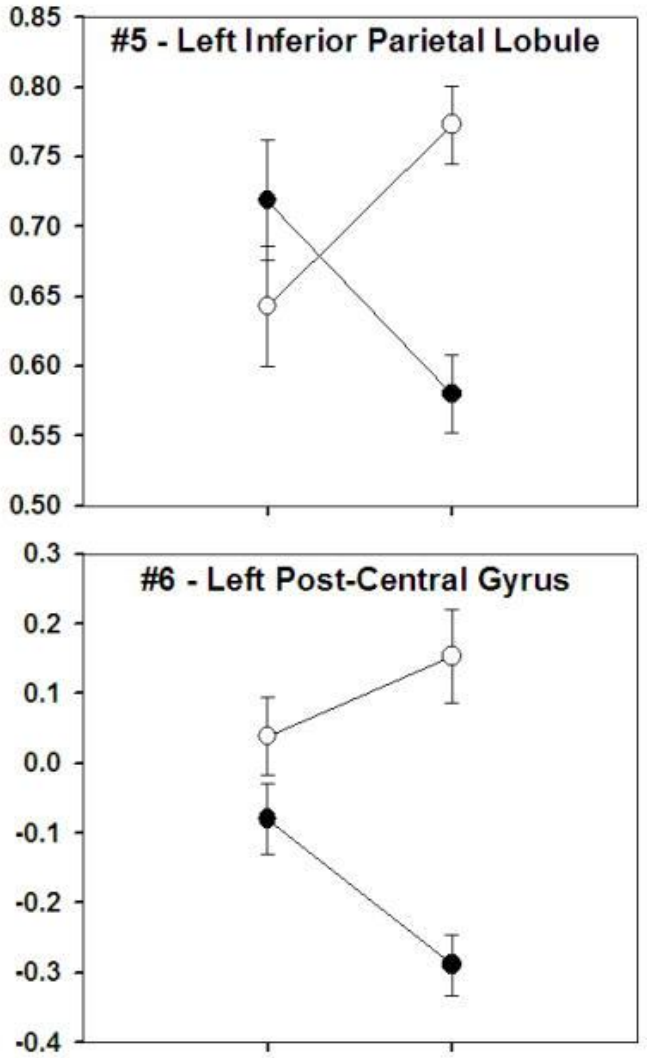

Famous Unfamiliar

Faces

Figure 2. Representative brain regions demonstrating interaction effects between Fame (Famous, Non-famous) and Stimulus Type (Face, Name). Numbers correspond to numbered regions in Table 3 and Figure 1C. MR Signal Intensity is in arbitrary units.

Table 1. Brain regions demonstrating differences in activation comparing Name vs. Face stimuli.

\begin{tabular}{|c|c|c|c|c|c|c|c|c|c|c|c|c|c|c|c|}
\hline \multicolumn{8}{|c|}{ Name $>$ Face } & \multicolumn{8}{|c|}{ Face $>$ Name } \\
\hline \# & Side & Region & BA & $\mathbf{x}$ & $\mathbf{y}$ & $\mathbf{z}$ & $\begin{array}{c}\text { Vol } \\
(\mathrm{ml})\end{array}$ & \# & Side & Region & BA & $\mathbf{x}$ & $\mathbf{y}$ & $\mathbf{z}$ & $\begin{array}{c}\text { Vol } \\
(\mathrm{ml})\end{array}$ \\
\hline & & & & & & & Fron & tal & & & & & & & \\
\hline 1 & L & Middle Frontal G. & 6 & 21 & -9 & 57 & 4.7 & & & & & & & & \\
\hline 2 & L & Precentral G. & 6 & 47 & -1 & 26 & 2.2 & & & & & & & & \\
\hline 3 & L & Precentral G. & 6 & 47 & -3 & 44 & 2.1 & & & & & & & & \\
\hline 4 & L & Cingulate G. & 24,32 & 14 & 35 & 0 & 1.4 & & & & & & & & \\
\hline 5 & L & Insular Cortex & - & $38^{-}$ & -3 & 10 & 4.6 & & & & & & & & \\
\hline 6 & $\mathrm{R}$ & Middle Frontal G. & 6 & 25 & $1 \overline{2}$ & 57 & 0.6 & 20 & $\mathrm{R}$ & $\begin{array}{l}\text { Superior Frontal } \\
\text { G. }\end{array}$ & 8 & 5 & 40 & 44 & 4.4 \\
\hline
\end{tabular}

Brain and Cognition, Vol 72, No. 3 (April 2010): pg. 491-498. DOI. This article is (C Elsevier and permission has been granted for this version to appear in e-Publications@Marquette. Elsevier does not grant permission for this article to be further copied/distributed or hosted elsewhere without the express permission from Elsevier. 
NOT THE PUBLISHED VERSION; this is the author's final, peer-reviewed manuscript. The published version may be accessed by following the link in the citation at the bottom of the page.

\begin{tabular}{|c|c|c|c|c|c|c|c|c|c|c|c|c|c|c|c|}
\hline \multicolumn{8}{|c|}{ Name $>$ Face } & \multicolumn{8}{|c|}{ Face $>$ Name } \\
\hline \# & Side & Region & BA & $\mathbf{x}$ & $\mathbf{y}$ & $\mathbf{z}$ & $\begin{array}{l}\text { Vol } \\
(\mathrm{ml})\end{array}$ & $\# \mathbf{s}$ & Side & Region & BA & $\mathbf{x}$ & $\mathbf{y}$ & $\mathbf{z}$ & $\begin{array}{l}\text { Vol } \\
(\mathrm{ml})\end{array}$ \\
\hline 7 & $\mathrm{R}$ & $\begin{array}{l}\text { Superior Frontal } \\
\text { G. }\end{array}$ & 6 & 10 & 12 & 62 & 0.3 & 21 & $\mathrm{R}$ & $\begin{array}{l}\text { Inferior Frontal } \\
\text { G. }\end{array}$ & 44 & 51 & 17 & 27 & 2.8 \\
\hline 8 & $\mathrm{R}$ & Cingulate G. & 24,32 & 14 & 39 & 5 & 2.7 & 22 & $\mathrm{R}$ & Insular Cortex & - & 37 & 22 & -8 & 1.2 \\
\hline \multicolumn{16}{|c|}{ Parietal } \\
\hline 9 & L & Supramarginal G. & 40 & $4 \overline{7}$ & 40 & 34 & 12.2 & & & & & & & & \\
\hline 10 & L & Precuneus & 7 & 18 & 57 & 51 & 7.7 & & & & & & & & \\
\hline 11 & L & Precuneus & 7 & 12 & 67 & 59 & 0.4 & & & & & & & & \\
\hline 12 & $\mathrm{R}$ & Postcentral G. & 1,2 & 35 & $42^{-}$ & 59 & 2.8 & 23 & $\mathrm{R}$ & $\begin{array}{l}\text { Posterior } \\
\text { Cingulate }\end{array}$ & 30 & 4 & 50 & 20 & 0.4 \\
\hline 13 & $\mathrm{R}$ & Postcentral G. & 1,2 & 54 & 20 & 23 & 2.5 & & & & & & & & \\
\hline 14 & $\mathrm{R}$ & $\begin{array}{l}\text { Inferior Parietal } \\
\text { L. }\end{array}$ & 40 & 55 & 39 & 46 & 0.5 & & & & & & & & \\
\hline \multicolumn{16}{|c|}{ Temporal } \\
\hline 15 & L & $\begin{array}{l}\text { Middle Temporal } \\
\text { G. }\end{array}$ & 21 & 47 & 50 & 0 & 6.3 & 24 & L & Fusiform G. & 37 & 24 & 71 & 12 & 5.2 \\
\hline \multirow[t]{3}{*}{16} & L & Sup. Temporal G. & 22 & $5 \overline{1}$ & $4 \overline{1}$ & 13 & 2.9 & 25 & $\mathrm{R}$ & Fusiform G. & 37 & 35 & 61 & $1 \overline{1}$ & 12.7 \\
\hline & & & & & & & & 26 & $\mathrm{R}$ & $\begin{array}{l}\text { Inferior } \\
\text { Temporal G. }\end{array}$ & 20 & 33 & $\begin{array}{r}- \\
11\end{array}$ & 28 & 0.4 \\
\hline & \multicolumn{15}{|c|}{ Occipital } \\
\hline 17 & L & Calcarine S. & 17 & -8 & 74 & 11 & 8.5 & 27 & L & Cuneus & 18 & 33 & 87 & 7 & 6.5 \\
\hline 18 & $\mathrm{R}$ & Cuneus & 17,18 & 10 & 76 & 16 & 9.2 & 28 & $\mathrm{R}$ & Cuneus & 18 & 38 & $80^{-}$ & 8 & 12.0 \\
\hline \multicolumn{16}{|c|}{ Cerebellum } \\
\hline 19 & $\mathrm{R}$ & $\begin{array}{l}\text { Lat. Hemi. } \\
\text { (VIIIA*) }\end{array}$ & - & 27 & $6 \overline{-}$ & 42 & 1.3 & 29 & L & $\begin{array}{l}\text { Lat. Hemi. } \\
\text { (VIIAt*) }\end{array}$ & - & -9 & 75 & 29 & 0.4 \\
\hline \multicolumn{16}{|c|}{ Subcortical } \\
\hline & & & & & & & & & $\mathrm{R}$ & $\begin{array}{l}\text { Superior } \\
\text { Colliculus }\end{array}$ & & 5 & 31 & -1 & 2.1 \\
\hline & & & & & & & & - & L & $\begin{array}{l}\text { Superior } \\
\text { Colliculus }\end{array}$ & & $1 \overline{7}$ & 30 & 0 & 0.6 \\
\hline
\end{tabular}

Note: \# corresponds with regions shown in Fig. $1 \mathrm{~A} ; \mathrm{BA}=$ Brodmann area; $\mathrm{L}=$ left; $\mathrm{R}$ $=$ right $; *=$ nomenclature from (Schmahmann et al., 1999)

Table 2. Brain regions demonstrating differences in activation comparing Famous vs. Unfamiliar stimuli.

Side Region

BA $x \quad y \quad z$ Vol. ( $\mathrm{ml})$

Famous > Unfamiliar

\section{Frontal}

\begin{tabular}{|c|c|c|c|c|c|}
\hline $\mathrm{L}$ & Superior Frontal G. & 8 & -11 & 34 & 46 \\
\hline $2 \mathrm{~L}$ & Superior Frontal G. & 10 & -1 & 55 & 15 \\
\hline
\end{tabular}

Brain and Cognition, Vol 72, No. 3 (April 2010): pg. 491-498. DOI. This article is (C Elsevier and permission has been granted for this version to appear in e-Publications@Marquette. Elsevier does not grant permission for this article to be further copied/distributed or hosted elsewhere without the express permission from Elsevier. 
NOT THE PUBLISHED VERSION; this is the author's final, peer-reviewed manuscript. The published version may be accessed by following the link in the citation at the bottom of the page.

\begin{tabular}{|c|c|c|c|c|c|c|c|}
\hline \multicolumn{3}{|c|}{ \# Side Region } & \multirow{2}{*}{$\frac{\text { BA }}{6}$} & \multirow{2}{*}{$\frac{x}{-32}$} & \multirow{2}{*}{$\frac{y}{6}$} & \multirow{2}{*}{$\frac{\mathbf{z}}{51}$} & \multirow{2}{*}{$\frac{\text { Vol. (ml) }}{1.1}$} \\
\hline 3 & $\mathrm{~L}$ & Middle Frontal G. & & & & & \\
\hline 4 & $\mathrm{~L}$ & Anterior Insula & - & -36 & 0 & 2 & 0.5 \\
\hline \multicolumn{8}{|c|}{ Parietal } \\
\hline 5 & $\mathrm{~L}$ & Temporoparietal Junction & 37,39 & -49 & -63 & 23 & 15.1 \\
\hline 6 & B & Posterior Cingulate & 23,31 & -2 & -52 & 25 & 12.4 \\
\hline 7 & $\mathrm{R}$ & Angular G. & 39 & 47 & -72 & 30 & 1.2 \\
\hline \multicolumn{8}{|c|}{ Temporal } \\
\hline 8 & $\mathrm{~L}$ & Middle Temporal G. & 21 & -54 & -41 & -6 & 3.8 \\
\hline 9 & $\mathrm{~L}$ & Middle Temporal G. & 21 & -52 & -16 & -10 & 0.3 \\
\hline 10 & $\mathrm{~L}$ & Superior Temporal G. & 38 & -41 & 14 & -21 & 1.1 \\
\hline 11 & $\mathrm{~L}$ & Middle Temporal G. & 21 & -44 & -1 & -31 & 0.5 \\
\hline 12 & $\mathrm{~L}$ & Hippocampus & - & -25 & -29 & -11 & 1.0 \\
\hline 13 & $\mathrm{R}$ & Hippocampus & - & 31 & -26 & -11 & 1.8 \\
\hline 14 & $\mathrm{R}$ & Middle Temporal G. & 21 & 59 & -5 & -9 & 1.3 \\
\hline 15 & $\mathrm{R}$ & Middle Temporal G. & 21 & 63 & -51 & 6 & 0.5 \\
\hline
\end{tabular}

Note: No brain areas showed Unfamiliar > Famous activity; \# corresponds with regions shown in Fig. $1 \mathrm{~B} ; \mathrm{BA}=$ Brodmann area; $\mathrm{L}=$ left; $\mathrm{R}=$ right; $\mathrm{B}=$ bilateral. 
NOT THE PUBLISHED VERSION; this is the author's final, peer-reviewed manuscript. The published version may be accessed by following the link in the citation at the bottom of the page.

\section{ROI Analyses}

Stimulus Type Table 1 and Figure $1 \mathrm{~A}$ present results of the Stimulus Type main effect. As expected, face processing produced greater activation than names principally in the fusiform and lateral occipital regions. These activations were bilateral, although a clear right hemisphere preference was evident for both areas. Right-sided activity was also observed in the superior and inferior frontal gyri and insula, as well as the posterior cingulate and inferior temporal gyrus. Bilateral activity was observed in the superior collicli. Name stimuli produced a widespread and predominantly left-sided activation that included the cuneus, middle and superior temporal gyrus, precuneus, supramarginal gyrus, precentral gyrus, and insula. Right side activation was also found in the cuneus, inferior parietal lobe, postcentral gyrus, anterior cingulate, and middle and superior frontal gyri.

Fame Results of the Fame main effect are presented in Table 2 and Figure 1B. Famous stimuli, collapsed over stimulus type, produced greater activation than non-famous stimuli predominantly in the left hemisphere including the temporoparietal junction, insula, and superior and middle frontal gyrus. Bilateral activation was observed for the hippocampi, posterior cingulate, and middle temporal gyrus. In contrast, no regions were detected in which non-famous stimuli demonstrated greater activation than famous stimuli.

Stimulus Type $X$ Fame Interaction Sixteen relatively small $(<3$ $\mathrm{ml}$ ), predominantly left-sided clusters demonstrating significant Stimulus by Fame interactions were observed distributed throughout the brain (see Table 3 and Figure 1C). Fourteen of 16 clusters demonstrated greater activation for famous vs. unfamiliar face stimuli, while 12 of these 16 also demonstrated greater activation for unfamiliar vs. famous names. Additionally, 12 of the 16 clusters demonstrated significantly greater activation for unfamiliar names vs. unfamiliar faces. Four clusters also demonstrated greater activation for famous faces vs. famous names while four different clusters demonstrated the opposite pattern. Figure 2 presents graphs illustrating these effects in four representative regions.

Brain and Cognition, Vol 72, No. 3 (April 2010): pg. 491-498. DOI. This article is @ Elsevier and permission has been granted for this version to appear in e-Publications@Marquette. Elsevier does not grant permission for this article to be further copied/distributed or hosted elsewhere without the express permission from Elsevier. 
Table 3. Brain regions demonstrating an interaction between Fame and Stimulus Type

\section{Side Region}

Frontal Lobe

1 L Precentral G.

2 M Supplemental Motor

3 L Middle Cingulate $\mathrm{G}$.

$4 \quad \mathrm{~L}$ Insula

\section{Parietal Lobe}

5 L Inferior Parietal L.

6 L Postcentral G.

\section{Temporal Lobe}

7 L Fusiform G.

$8 \mathrm{~L}$ Superior Temporal G.

\section{Occipital Lobe}

9 L Lingual G.

$10 \mathrm{~L}$ Lingual $\mathrm{G}$.

11 L Inferior Occipital G.

$12 \mathrm{R}$ Inferior Occipital G.

\section{Cerebellum}

$$
\begin{array}{rll}
13 & \text { M } & \text { Vermis }\left(I V, V^{*}\right) \\
14 & \text { R } & \begin{array}{l}
\text { Lateral Hemisphere } \\
\left(I^{*}\right)
\end{array}
\end{array}
$$

\section{Subcortical}

Vol Interaction

BA $x \quad y \quad z \quad(m l)$ Contrasts

$\begin{array}{lrrrrl}6 & 49 & -4 & 37 & 2.3 & \text { A, C } \\ 6 & -3 & -1 & 58 & 0.5 & \text { A, B, E, F } \\ 24 & -3 & - & 40 & 0.5 & \text { A, B, C, D } \\ & - & 10 & & & \\ - & 45 & 6 & 3 & 0.4 & \text { A, B, C }\end{array}$


NOT THE PUBLISHED VERSION; this is the author's final, peer-reviewed manuscript. The published version may be accessed by following the link in the citation at the bottom of the page.

Unfamiliar $>$ Famous, Names; $\mathrm{C}=$ Names $>$ Faces, Unfamiliar; $\mathrm{D}=$ Names $>$ Faces, Famous; $\mathrm{E}=$ Faces $>$ Names, Unfamiliar; $\mathrm{F}=$ Faces $>$ Names, Famous.

\section{Discussion}

This event-related fMRI study directly compared famous and non-famous names with famous and non-famous faces in order to determine the impact of stimulus type (face versus names) and familiarity (famous or non-famous) on the neural networks associated with person identity. Both famous faces and famous names produced more activation than non-famous faces and names consistent with several other studies (Douville et al., 2005; Gorno-Tempini et al., 1998; Leveroni et al., 2000). However, it should be noted that the same pattern of findings is not always observed for non-familiar faces without a preexisting semantic context that is represented multiple times to create a sense of familiarity (Rossion, Schiltz, Robaye, Pirenne, \& Crommelinck, 2001).

Our findings implicate an integrated set of shared and modality specific areas of activation which appear to work in concert in the recognition of familiar people (faces or names). There was also evidence for additional areas of activation in the right hemisphere for faces and in the left hemisphere for names, but bilateral activity was also noted for both faces and names beginning in the early stages of stimulus processing. This highlights the point that successful recognition of famous faces involves a complex set of interrelated bilateral structures (Cooper, Harvey, Lavidor, \& Schweinberger, 2007; Mohr, Landgrebe, \& Schweinberger, 2002; Rossion et al., 2003). A similar point has been made with respect to categorization of famous names. That is, performance for discriminating famous names was found to be similar when names were presented in either the right or left visual field (Ohnesorge \& Van Lancker, 2001).

Haxby and colleagues $(2000 ; 2007)$ proposed a neural model for the recognition of familiar faces, which can serve as a useful framework to discuss the current findings. They suggested that a distributed neural system composed of both a core system and an extended system underlies the recognition of a familiar face. The core system entails the visual analysis of the face and includes the inferior occipital and fusiform gyrus and the posterior superior temporal

Brain and Cognition, Vol 72, No. 3 (April 2010): pg. 491-498. DOI. This article is @ Elsevier and permission has been granted for this version to appear in e-Publications@Marquette. Elsevier does not grant permission for this article to be further copied/distributed or hosted elsewhere without the express permission from Elsevier. 
sulcus. The extended system is made up of two components, person knowledge and emotion, with each component presumably including several neural regions. Person knowledge includes biographical information (anterior temporal cortex), retrieval of personal traits, attitudes, and mental states (anterior paracingulate), mental states and intentions (superior temporal sulcus, temporo-parietal junction), and retrieval of episodic memory (precuneus/posterior cingulate). The emotion component includes the insula, amygdala, and striatum, which are presumably linked to emotional reactions to familiar faces.

Consistent with the Haxby model, we found that familiar faces produced greater activity than familiar names in regions associated with the pre-semantic core visual analysis stage (e.g., fusiform gyrus), as well as other regions shown to play a role in visual analyses (e.g., right cuneus, right inferior temporal gyrus). These findings are consistent with previous reports identifying the role of the occipitotemporal region in mediating famous faces, and the interaction of the fusiform gyrus with the lateral occipital region in familiar face processing (Minnesbusch, Suchan, Köster, \& Daum, 2009; Rossion et al., 2003). In contrast to faces, famous names did not produce increased activity in the fusiform gyrus, consistent with the notion that this region plays a unique role in person identity based on a facial presentation (Grill-Spector \& Malach, 2001). Importantly however, the fusiform has also been associated with cross-modal responses to familiar persons, such as when hearing familiar voices when the task involves speaker recognition rather than message content (Von Kriegstein, Kleinschmidt, Sterzer, \& Giraud, 2005). Famous names instead produced more activity than famous faces in a set of regions including the cuneus and precuneus, areas that were also activated in another study when subjects were instructed to produce a mental image of a famous face generated from the presentation of the name of the person (Ishai, Haxby, \& Ungerleider, 2002). Activation unique to famous names was also observed in the left SMG, which is thought to play an important role in visual word recognition, regardless of specific task demands (Stoeckel, Gough, Watkins, \& Devlin, 2009).

There was evidence for hemispheric differences in both the number of regions and spatial extent of activation for famous names and famous faces. Famous names activated more left hemisphere regions than right hemisphere regions and also activated more left

Brain and Cognition, Vol 72, No. 3 (April 2010): pg. 491-498. DOI. This article is $@$ Elsevier and permission has been granted for this version to appear in e-Publications@Marquette. Elsevier does not grant permission for this article to be further copied/distributed or hosted elsewhere without the express permission from Elsevier. 
hemisphere regions in total than did famous faces. Conversely, famous faces produced more right hemisphere regions of activation than left hemisphere regions, and more right hemisphere areas in total than did famous names. Thus, these findings lend support to hemisphericassociated modality-specific processing for famous faces and famous names (Eslinger, 1996; Gainotti, 2007; Gorno-Tempini et al., 1998; Schweinberger et al., 2002).

In addition to the modality specific activations, there was also considerable common overlap of activation for both familiar faces and familiar names in a set of regions associated with the retrieval of biographical semantic information including bilateral hippocampus, left temporo-parietal junction, bilateral middle temporal gyrus, and bilateral posterior cingulate. Consistent with other reports, additional regions activated by fame recognition were primarily left lateralized and included the superior and middle frontal gyrus (Gorno-Tempini et al., 1998). Frontal regions have been found to be activated in several previous studies of famous faces or famous names (Douville et al., 2005; Grabowski, Damasio, \& Damasio, 1998; Leveroni et al., 2000), and may relate to the search and retrieval of person identity semantic information. Activation of the $\mathrm{HC}$ may reflect the retrieval aspects of accessing information from long-term semantic memory. Several recent fMRI studies have found increased hippocampal activity for the recognition of famous people (faces or names) from both recent and remote time periods (Bernard et al., 2004; Douville et al., 2005).

Of interest, bilateral activity in the posterior cingulate has consistently been reported for both famous faces and famous names (Leveroni et al., 2000; Woodard et al., 2007). It also has been found to be active in response to familiar voices compared to non-famous voices (Arnott, Heywood, Kentridge, \& Goodale, 2008; Shah et al., 2001). Thus, the posterior cingulate may play an important role in the amodal access to information about familiar people. Maddock (1999) emphasized the potential role of the posterior cingulate, and the retrosplenial cortex in particular, in processing emotionally salient information. Fame irrespective of stimulus modality also produced activation in the temporoparietal junction (TPJ), insula, and middle frontal gyrus. These regions, in particular the TPJ, are considered to play an important role in social cognition (i.e., theory of mind) such as in drawing inferences about the goals and intentions of other people

Brain and Cognition, Vol 72, No. 3 (April 2010): pg. 491-498. DOI. This article is @ Elsevier and permission has been granted for this version to appear in e-Publications@Marquette. Elsevier does not grant permission for this article to be further copied/distributed or hosted elsewhere without the express permission from Elsevier. 
(Samson, Apperly, Chiavarino, \& Humphreys, 2004; Saxe \& Kanwisher, 2003; Van Overwalle, 2009). One would expect that these social-emotional and attitudinal processes would be critical in determining responses to people we meet and interact with, regardless of stimulus modality.

We found a common area of activation for both famous faces and famous names in the area of the left anterior temporal lobe, but not the right anterior temporal lobe which has often been cited in lesion studies as important in the recognition of famous people (Evans et al., 1995; Gainotti, Barbier, \& Marra, 2003; Gentileschi, Sperber, \& Spinnler, 1999). The observed left temporal lobe activity also did not extend out to the temporal pole as reported by others (Gorno-Tempini et al., 1998). In the current study, subjects were asked to make a familiarity judgment about the famous face, but it is quite likely that making this decision also ("automatically") elicited the retrieval of the individual name and accompanying semantic information. Left anterior temporal lobe activity has been reported in other studies that entailed naming of famous faces (Grabowski et al., 2001). Furthermore, famous face naming (in contrast to face recognition) is specifically disrupted in patients with left temporal lobe epilepsy (Glosser, Salvucci, \& Chiaravalloti, 2003; Seidenberg et al., 2002; Viskontas, McAndrews, \& Moscovitch, 2002). The issue of task performance and its impact on temporal pole activation has also been raised in another fMRI study examining categorization of famous faces (Turk, Rosenblum, Gazzaniga, \& Macrae, 2005). It should also be noted that concern has also been raised about the FMRI BOLD imaging limitations in the temporal poles (Devlin et al., 2000). Additional neuroimaging studies may help to resolve some of the inconsistencies seen in the neuroimaging literature on this point.

There were very few areas showing significant interactions between stimulus type and fame, and those that existed involved very small regions in distributed areas primarily in the left hemisphere. In these few regions, famous faces produced greater activity than nonfamous faces, while non-famous names produced greater activity than famous names. We can only speculate at this time about this discrepancy, but anecdotal reports from participants suggested that non-famous faces were more easily rejected than were non-famous

Brain and Cognition, Vol 72, No. 3 (April 2010): pg. 491-498. DOI. This article is @ Elsevier and permission has been granted for this version to appear in e-Publications@Marquette. Elsevier does not grant permission for this article to be further copied/distributed or hosted elsewhere without the express permission from Elsevier. 
names. That is, non-famous names may have required more detailed processing to make a decision about fame than did non-famous faces.

One important limitation of the current study is the difficulty in determining the specific level of processing performed by subjects in the famous face and name recognition task. It is generally acknowledged that when one recognizes a familiar face or name, there is also a degree of "automatic" retrieval of more detailed semantic information (Gorno-Tempini et al., 1998). However, the degree of "internal" processing is likely to vary across subjects and famous stimuli. Thus, there may be subtle differences in the neural networks that are activated depending on the level of person processing that has been achieved (Turk et al., 2005). In addition, there was a significant difference in task difficulty between the stimulus sets, whereby faces were slightly more difficult to recognize or reject than were names. However, all mean performances were $90 \%$ correct or better, suggesting that this significant effect is attributable at least in part to ceiling effects. That is, faces were judged at 90-91\% accuracy, while names were judged at 95-97\% accuracy, so that given the restricted range of performance at near perfect levels, this small difference was statistically significant. However, it is most important to note that the hemodynamic response functions for the functional analyses included only correctly performed trials in order to limit task performance effects.

\section{Conclusions}

The present study provides results consistent with both modality specific and amodal models of familiar person processing. Both the face and name modality of famous people activated distinct regions in the right and left hemisphere which are typically associated with presemantic processing. In addition, a set of shared regions that are typically associated with retrieval of biographical knowledge and social affective reaction were also activated regardless of modality of presentation. This latter network includes regions commonly associated with long-term memory retrieval (e.g., bilateral hippocampal and posterior cingulate), as well as those specifically associated with biographical knowledge storage and retrieval (e.g.,

Brain and Cognition, Vol 72, No. 3 (April 2010): pg. 491-498. DOI. This article is @ Elsevier and permission has been granted for this version to appear in e-Publications@Marquette. Elsevier does not grant permission for this article to be further copied/distributed or hosted elsewhere without the express permission from Elsevier. 
anterior and middle temporal regions), and emotional components (e.g., insula, TPJ, and anterior cingulate).

\section{Acknowledgments}

This project was supported by AG022304 from the National Institute on Aging, the Medical College of Wisconsin General Clinical Research Center (M01 RR00058), and the W.M. Keck Foundation. The content is solely the responsibility of the authors and does not necessarily represent the official views of the National Institute on Aging or the National Institutes of Health.

Publisher's Disclaimer: This is a PDF file of an unedited manuscript that has been accepted for publication. As a service to our customers we are providing this early version of the manuscript. The manuscript will undergo copyediting, typesetting, and review of the resulting proof before it is published in its final citable form. Please note that during the production process errors may be discovered which could affect the content, and all legal disclaimers that apply to the journal pertain.

\section{References}

Arnott SR, Heywood CA, Kentridge RW, Goodale MA. Voice recognition and the posterior cingulate: an fMRI study of prosopagnosia. J Neuropsychol. 2008;2(Pt 1):269-286.

Bernard FA, Bullmore ET, Graham KS, Thompson SA, Hodges JR, Fletcher PC. The hippocampal region is involved in successful recognition of both remote and recent famous faces. Neuroimage. 2004;22(4):17041714.

Bruce $V$, Young A. Understanding face recognition. British Journal of Psychology. 1986;77(Pt 3):305-327.

Burton AM, Bruce $\mathrm{V}$, Johnston RA. Understanding face recognition with an interactive activation model. British Journal of Psychology. 1990;81(Pt 3):361-380.

Cooper TJ, Harvey M, Lavidor M, Schweinberger SR. Hemispheric asymmetries in image-specific and abstractive priming of famous

Brain and Cognition, Vol 72, No. 3 (April 2010): pg. 491-498. DOI. This article is (C) Elsevier and permission has been granted for this version to appear in e-Publications@Marquette. Elsevier does not grant permission for this article to be further copied/distributed or hosted elsewhere without the express permission from Elsevier. 
NOT THE PUBLISHED VERSION; this is the author's final, peer-reviewed manuscript. The published version may be accessed by following the link in the citation at the bottom of the page.

faces: evidence from reaction times and event-related brain potentials. Neuropsychologia. 2007;45(13):2910-2921.

Cox RW. AFNI: Software for analysis and visualization of functional magnetic resonance neuroimages. Computers and Biomedical Research. $1996 ; 29: 162-173$.

Devlin JT, Russell RP, Davis MH, Price CJ, Wilson J, Moss HE, et al. Susceptibility-induced loss of signal: comparing PET and fMRI on a semantic task. Neuroimage. 2000;11(6 Pt 1):589-600.

Douville KL, Woodard JL, Seidenberg M, Leveroni CL, Nielson KA, Franczak M, et al. Medial temporal lobe activity for recognition of recent and remote famous names: an event-related fMRI study. Neuropsychologia. 2005;43:693-703.

Eslinger $\mathrm{P}, \mathrm{E} \mathrm{A}, \mathrm{G} \mathrm{L}, \mathrm{VH}$ G. Distinctive forms of partial retrograde amnesia afetr asymmetric temporal lobe lesions: Possible role of the occipitotemporal gyri in memory. Cerebral Cortex. 1996;6:530-539.

Evans JJ, Heggs AJ, Antoun N, Hodges JR. Progressive prosopagnosia associated with selective right temporal lobe atrophy. A new syndrome? Brain. 1995;118(Pt 1):1-13.

Forman SD, Cohen JD, Fitzgerald M, Eddy WF, Mintun MA, Noll DC. Improved assessment of significant activation in functional magnetic resonance imaging (fMRI): use of a cluster-size threshold. Magn Reson Med. $1995 ; 33(5): 636-647$.

Gainotti G. Different patterns of famous people recognition disorders in patients with right and left anterior temporal lesions: a systematic review. Neuropsychologia. 2007;45(8):1591-1607.

Gainotti G, Barbier A, Marra C. Slowly progressive defect in recognition of familiar people in a patient with right anterior temporal atrophy. Brain. 2003;126(Pt 4):792-803.

Gentileschi V, Sperber S, Spinnler H. Progressive defective recognition of familiar people. Neurocase. 1999;5:407-424.

Glosser G, Salvucci AE, Chiaravalloti ND. Naming and recognizing famous faces in temporal lobe epilepsy. Neurology. 2003;61(1):81-86.

Brain and Cognition, Vol 72, No. 3 (April 2010): pg. 491-498. DOI. This article is (c) Elsevier and permission has been granted for this version to appear in e-Publications@Marquette. Elsevier does not grant permission for this article to be further copied/distributed or hosted elsewhere without the express permission from Elsevier. 
NOT THE PUBLISHED VERSION; this is the author's final, peer-reviewed manuscript. The published version may be accessed by following the link in the citation at the bottom of the page.

Gobbini MI, Haxby JV. Neural systems for recognition of familiar faces. Neuropsychologia. 2007;45(1):32-41.

Gorno-Tempini ML, Price CJ, Josephs O, Vandenberghe R, Cappa SF, Kapur N, et al. The neural systems sustaining face and proper-name processing. Brain. 1998;121(Pt 11):2103-2118.

Grabowski TJ, Damasio H, Damasio AR. Premotor and prefrontal correlates of category-related lexical retrieval. Neuroimage. 1998;7(3):232-243.

Grabowski TJ, Damasio H, Tranel D, Ponto LL, Hichwa RD, Damasio AR. A role for left temporal pole in the retrieval of words for unique entities. Hum Brain Mapp. 2001;13(4):199-212.

Grill-Spector K, Malach R. fMR-adaptation: A tool for studying the functional properties of human cortical neurons. Acta Psychologica. 2001;107:293-321.

Haslam C, Kay J, Hanley JR, Lyons F. Biographical knowledge: modalityspecific or modality-neutral? Cortex. 2004;40(3):451-466.

Haxby JV, Hoffman EA, Gobbini MI. The distributed human neural system for face perception. Trends Cogn Sci. 2000;4(6):223-233.

Haxby JV, Ida Gobbini M. The perception of emotion and social cues in faces. Neuropsychologia. 2007;45(1):1

Ishai A, Haxby JV, Ungerleider LG. Visual imagery of famous faces: effects of memory and attention revealed by fMRI. Neuroimage. 2002;17(4):1729-1741.

Ishai $A$, Schmidt CF, Boesiger P. Face perception is mediated by a distributed cortical network. Brain Res Bull. 2005;67(1-2):87-93.

Kapur N, Friston KJ, Young A, Frith CD, Frackowiak RS. Activation of human hippocampal formation during memory for faces: a PET study. Cortex. 1995;31(1):99-108.

Kartsounis LD, Shallice T. Modality specific semantic knowledge loss for unique items. Cortex. 1996;32(1):109-119.

Lambert NA, Swain MA, Miller LA, Caine D. Exploring the neural organization of person-related knowledge: lateralization of lesion, category

Brain and Cognition, Vol 72, No. 3 (April 2010): pg. 491-498. DOI. This article is @ Elsevier and permission has been granted for this version to appear in e-Publications@Marquette. Elsevier does not grant permission for this article to be further copied/distributed or hosted elsewhere without the express permission from Elsevier. 
NOT THE PUBLISHED VERSION; this is the author's final, peer-reviewed manuscript. The published version may be accessed by following the link in the citation at the bottom of the page.

specificity, and stimulus modality effects. Neuropsychology. $2006 ; 20(3): 346-354$.

Leveroni CL, Seidenberg M, Mayer AR, Mead LA, Binder JR, Rao SM. Neural systems underlying the recognition of familiar and newly learned faces. Journal of Neuroscience. $2000 ; 20(2): 878-886$.

Maddock RJ. The retrosplenial cortex and emotion: new insights from functional neuroimaging of the human brain. Trends Neurosci. $1999 ; 22(7): 310-316$.

Minnesbusch DA, Suchan B, Köster O, Daum I. A bilateral occipitotemporal network mediates face perception. Behavioural Brain Research. 2009;198:179-185.

Mohr B, Landgrebe A, Schweinberger SR. Interhemispheric cooperation for familiar but not unfamiliar face processing. Neuropsychologia. 2002;40(11):1841-1848.

Nielson KA, Douville KL, Seidenberg M, Woodard JL, Miller SK, Franczak M, et al. Age-related functional recruitment for famous name recognition: an event-related fMRI study. Neurobiology of Aging. 2006;27(10):14941504. [PMC free article]

Ohnesorge C, Van Lancker D. Cerebral laterality for famous proper nouns: visual recognition by normal subjects. Brain Lang. $2001 ; 77(2): 135-$ 165.

Pfutze EM, Sommer W, Schweinberger SR. Age-related slowing in face and name recognition: evidence from event-related brain potentials. Psychol Aging. 2002;17(1):140-160.

Rossion B, Caldara R, Seghier M, Schuller AM, Lazeyras F, Mayer E. A network of occipito-temporal face-sensitive areas besides the right middle fusiform gyrus is necessary for normal face processing. Brain. 2003;126(Pt 11):2381-2395.

Rossion B, Schiltz C, Robaye L, Pirenne D, Crommelinck M. How does the brain discriminate familiar and unfamiliar faces?: a PET study of face categorical perception. J Cogn Neurosci. 2001;13(7):1019-1034.

Brain and Cognition, Vol 72, No. 3 (April 2010): pg. 491-498. DOI. This article is @ Elsevier and permission has been granted for this version to appear in e-Publications@Marquette. Elsevier does not grant permission for this article to be further copied/distributed or hosted elsewhere without the express permission from Elsevier. 
NOT THE PUBLISHED VERSION; this is the author's final, peer-reviewed manuscript. The published version may be accessed by following the link in the citation at the bottom of the page.

Samson D, Apperly IA, Chiavarino C, Humphreys GW. Left temporoparietal junction is necessary for representing someone else's belief. Nat Neurosci. 2004;7(5):499-500.

Saxe R, Kanwisher N. People thinking about thinking people. The role of the temporo-parietal junction in "theory of mind" Neuroimage. $2003 ; 19(4): 1835-1842$.

Schweinberger SR, Pickering EC, Burton AM, Kaufmann JM. Human brain potential correlates of repetition priming in face and name recognition. Neuropsychologia. 2002;40(12):2057-2073.

Seidenberg M, Griffith R, Sabsevitz D, Moran M, Haltiner A, Bell B, et al. Recognition and identification of famous faces in patients with unilateral temporal lobe epilepsy. Neuropsychologia. 2002;40(4):446456.

Sergent J, Ohta S, MacDonald B. Functional neuroanatomy of face and object processing. A positron emission tomography study. Brain. 1992;115(Pt 1):15-36.

Shah NJ, Marshall JC, Zafiris O, Schwab A, Zilles K, Markowitsch HJ, et al. The neural correlates of person familiarity. A functional magnetic resonance imaging study with clinical implications. Brain. 2001;124(Pt 4):804-815.

Snowden JS, Thompson JC, Neary D. Knowledge of famous faces and names in semantic dementia. Brain. 2004;127(Pt 4):860-872.

Stoeckel C, Gough PM, Watkins KE, Devlin JT. Supramarginal gyrus involvement in visual word recognition. Cortex. 2009;45(9):10911096.

Talairach J, Tournoux P. Co-planar stereotaxic atlas of the human brain. New York: Thieme; 1988.

Turk DJ, Rosenblum AC, Gazzaniga MS, Macrae CN. Seeing John Malkovich: the neural substrates of person categorization. Neuroimage. 2005;24(4):1147-1153.

Van Overwalle F. Social cognition and the brain: a meta-analysis. Human Brain Mapping. 2009;30:829-858.

Brain and Cognition, Vol 72, No. 3 (April 2010): pg. 491-498. DOI. This article is @ Elsevier and permission has been granted for this version to appear in e-Publications@Marquette. Elsevier does not grant permission for this article to be further copied/distributed or hosted elsewhere without the express permission from Elsevier. 
NOT THE PUBLISHED VERSION; this is the author's final, peer-reviewed manuscript. The published version may be accessed by following the link in the citation at the bottom of the page.

Viskontas IV, McAndrews MP, Moscovitch M. Memory for famous people in patients with unilateral temporal lobe epilepsy and excisions.

Neuropsychology. 2002;16(4):472-480.

Von Kriegstein K, Kleinschmidt A, Sterzer P, Giraud AL. Interaction of face and voice areas during speaker recognition. Journal of Cognitive Neuroscience. 2005;17(3):367-376.

Ward BD. Simultaneous inference for fMRI data. 2000.

Wiggett AJ, Downing PE. The face network: overextended? (Comment on: "Let's face it: It's a cortical network" by Alumit Ishai) Neuroimage. 2008;40(2):420-422.

Woodard JL, Seidenberg M, Nielson KA, Miller SK, Franczak M, Antuono P, et al. Temporally graded activation of neocortical regions in response to memories of different ages. Journal of Cognitive Neuroscience. 2007;19(7):1113-1124. 